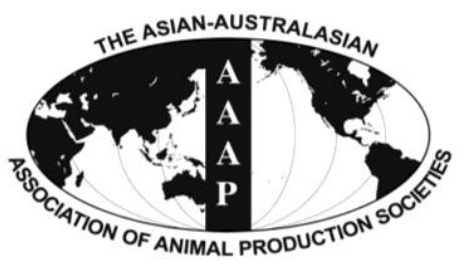

Asian Australas. J. Anim. Sci.

Vol. 26, No. 11 : 1553-1561 November 2013

http://dx.doi.org/10.5713/ajas.2013.13216

www.ajas.info

pISSN 1011-2367 elSSN 1976-5517

\title{
Influence of lonophore Supplementation on Growth Performance, Dietary Energetics and Carcass Characteristics in Finishing Cattle during Period of Heat Stress
}

\author{
A. Barreras, B. I. Castro-Pérez ${ }^{1}$, M. A. López-Soto, N. G. Torrentera, M. F. Montaño, A. Estrada-Angulo ${ }^{1}$, \\ F. G. Ríos ${ }^{1}$, H. Dávila-Ramos ${ }^{1}$, A. Plascencia*, and R. A. Zinn ${ }^{2}$ \\ Research Institute of Veterinary Sciences, University Autonomous of Baja California, México
}

\begin{abstract}
Forty-eight crossbred heifers $(378.1 \pm 18 \mathrm{~kg}$ ) were used in a 56-d feeding trial (four pens per treatment in a randomised complete block design) to evaluate the influence of ionophore supplementation on growth performance, dietary energetics and carcass characteristics in finishing cattle during a period of heat stress. Heifers were fed a diet based on steam-flaked corn (2.22 Mcal NE $/ \mathrm{kg})$ with and without an ionophore. Treatments were: i) control, no ionophore; ii) $30 \mathrm{mg} / \mathrm{kg}$ monensin sodium (RUM30); iii) $20 \mathrm{mg} / \mathrm{kg}$ lasalocid sodium (BOV20), and iv) $30 \mathrm{mg} / \mathrm{kg}$ lasalocid sodium (BOV30). Both dry matter intake (DMI) and climatic variables were measured daily and the temperature humidity index (THI) was estimated. The maximum THI during the study averaged 93, while the minimum was 70 (THI average $=79.2 \pm 2.3$ ). Compared to controls, monensin supplementation did not influence average daily gain, the estimated NE value of the diet, or observed-to-expected DMI, but tended ( $\mathrm{p}=0.07)$ to increase $(4.8 \%)$ gain to feed. Compared to controls, the group fed BOV30 increased $(\mathrm{p} \leq 0.03)$ daily gain $(11.8 \%)$, gain to feed $(8.3 \%)$, net energy of the diet $(5 \%)$, and observed-toexpected DMI $(5.2 \%)$. Daily weight gain was greater $(7.6 \%, \mathrm{p}=0.05)$ for heifers fed BOV30 than for heifers fed MON30. Otherwise, differences between the two treatments in DMI, gain to feed, and dietary NE were not statistically significant ( $p>0.11)$. Plotting weekly intakes versus THI, observed intake of controls was greater $(\mathrm{p}<0.05)$ at THI values $\leq 77$ than ionophore groups. When THI values were greater than 79, DMI of control and MON30 were not different $(\mathrm{p}=0.42)$, although less than that of groups fed lasalocid $(\mathrm{p}=0.04)$. Variation in energy intake was lower $(p>0.05)$ in the ionophores group $(\mathrm{CV}=1.7 \%)$ than in the control group $(\mathrm{CV}=4.5 \%)$. Inclusion of ionophores in the diet resulted in relatively minor changes in carcass characteristics. It is concluded that ionophore supplementation did not exacerbate the decline of DM intake in heat-stressed cattle fed a high-energy finishing diet; on the contrary, it stabilised feed intake and favoured feed efficiency. Ionophore supplementation reduced estimated maintenance coefficients around $10 \%$ in finishing cattle during a period of heat stress. This effect was greatest for heifers supplemented with $30 \mathrm{mg}$ lasalocid/kg of diet. (Key Words: Monensin, Lasalocid, Feedlot Cattle, Heat Stress, Performance)
\end{abstract}

\section{INTRODUCTION}

Supplementation of feedlot diets with either lasalocid or monensin may improve gain efficiency (Berger et al., 1981; Delfino et al., 1988). This effect has been attributed, in part, to shifts in ruminal fermentation patterns toward reduced methane energy loss (Bergen and Bates, 1984; Russell and Strobel, 1988). Both monensin and lasalocid

\footnotetext{
* Corresponding Author: Alejandro Plascencia. Tel: +52-6865636906 (111), Fax: +52-686-5636907, E-mail: aplas_99@ yahoo.com

${ }^{1}$ Veterinary School, University Autonomous of Sinaloa, México.

${ }^{2}$ Department of Animal Science, University of California, Davis, USA.

Submitted Apr. 16, 2013; Accepted Jul. 3, 2013; Revised Jul. 21, 2013
}

supplementation may decreases dry matter intake in feedlot cattle (Zinn, 1987; Duffield et al., 2012). However, monensin tends to depress feed intake to a greater extent than lasalocid (Zinn, 1987; NRC, 2000), presumably due to the comparatively lower palatability of monensin (Erickson et al., 2004). The potential negative impact of this extra caloric effect of monensin on feed intake may be greater when feed intake of cattle is already depressed by sustained stress conditions, such as during the receiving period (Duff and Galyean, 2007), or during periods of prolonged heat (NRC, 1981; 1987; Hahn, 1999; Mader, 2003). Igono et al. (1992) proposed that the Temperature Humidity Index (THI) could be used to evaluate environmental heat stress. This index combines relative humidity and temperature into a single value to estimate the potential environmental heat 
load. An environment is generally considered stressful for cattle when the THI exceeds 72 . In prolonged periods of summer time in northwestern Mexico the THI value exceeds 78 (Correa-Calderón et al., 2012; Macías-Cruz et al., 2013). Unfortunately, very little information is available regarding the comparative impact of lasalocid versus monensin supplementation on DMI patterns, growth performance, and carcass characteristics in feedlot cattle during periods of high ambient temperature (THI value $>72$ ).

Our objective was to compare the effect of monensin and lasalocid supplementation on the growth performance, dietary energetics, and carcass characteristics of feedlot cattle fed a high-energy finishing diet during a period of heat stress.

\section{MATERIALS AND METHODS}

All animal management procedures were conducted within the guidelines of locally-approved techniques for animal use and care (NOM-051-ZOO-1995: humanitarian care of animals during mobilisation of animals; NOM-062ZOO-1995: technical specifications for the care and use of laboratory animals. Livestock farms, farms, centres of production, reproduction and breeding, zoos and exhibition halls, must meet the basic principles of animal welfare; NOM-024-ZOO-1995: animal health stipulations and characteristics during the transportation of animals).

\section{Experimental location}

The trial was conducted during the summer at the Feedlot Experimental Unit of the Instituto de Investigaciones en Ciencias Veterinarias, Universidad Autónoma de Baja California, in the Mexicali Valley, northwestern Mexico (32 $40^{\prime} 7^{\prime \prime} \mathrm{N} ; 115^{\circ} 28^{\prime} 6^{\prime \prime} \mathrm{W}$, about 10 $\mathrm{m}$ above sea level, and under Sonoran desert conditions ( $B W h$ classification according to Köppen). This region is characterised as dry and arid with extreme temperatures in summer $\left(\geq 42^{\circ} \mathrm{C}\right)$, and an average annual precipitation of 85 mm (García, 1985).

\section{Weather measurement and THI estimation}

Climatic variables (ambient temperature, relative humidity, solar radiation, black globe temperature, and wind speed) were obtained every $30 \mathrm{~min}$ from an on-site weather station (UABC climatic experimental station) throughout the experimental period. The temperature humidity index was calculated using the following formula: $\mathrm{THI}=0.81 \times T$ +RH (T-14.40)+46.40 (Hahn, 1999).

\section{Animal management and treatments}

Forty-eight crossbred heifers $(378.1 \pm 18 \quad \mathrm{~kg})$, approximately $20 \%$ Zebú breeding with the remainder represented by Hereford, Angus, and Charolais breeds in various proportions, were used in a 56-d growth performance trial to evaluate the treatment effects on growth performance and carcass characteristics. The experiment was conducted during the summer months of August-September. The cattle originated from Sonora, Mexico, and were on feed at a commercial feedlot for $86 \mathrm{~d}$ before being transported $(7 \mathrm{~km})$ to the UABC feedlot research unit. Three days after arrival to commercial feedlot (83 d before the cattle were moved to the feedlot experimental unit), heifers were weighed, vaccinated for bovine rhinotracheitis-parainfluenza ${ }_{3}$ and Mannheimia haemolityca (Pirámide 4+Presponse SQ, Fort Dodge, Animal Health, México), clostridials (Ultrabac-7, Pfizer Animal Health, México), and treated for parasites (Bimectin, Vetoquinol, México). Heifers were injected with 500,000 IU vitamin A (Synt-ADE, Fort Dodge, Animal Health, México) and implanted with $200 \mathrm{mg}$ of testosterone propionate and $20 \mathrm{mg}$ of estradiol benzoate (Synovex $\mathrm{H}$, Fort Dodge, Animal Health, México). The cattle were transported to the feedlot research facilities and then were backgrounded for an additional $30 \mathrm{~d}$ before the trial started, heifers were weighed, reimplanted with $200 \mathrm{mg}$ of trembolone acetate and $28 \mathrm{mg}$ of estradiol benzoate (Synovex plus, Fort Dodge, Animal Health, México) and sorted by arrival live weight (LW) from lightest to heaviest, and were blocked by weight and randomly assigned within 4 weight groups to 16 pens (four heifers per pen). Pens were $50 \mathrm{~m}^{2}$ with $21 \mathrm{~m}^{2}$ overhead shade, automatic waterers and $3.7 \mathrm{~m}$ fence-line feed bunks. Cattle were weighed upon arrival to the research facilities, at the start of experiment, and before heifers were shipped to a federal inspection type slaughterhouse (TIF 105) located $14 \mathrm{~km}$ from the Feedlots Experimental Unit facilities. Individually, LW was recorded at $0600 \mathrm{~h}$. All heifers were fed a steam-flaked corn-based diet (Table 1) and were adapted to the control diet (no ionophore) $21 \mathrm{~d}$ before the trial started. Treatments were: i) control, no ionophore; ii) $30 \mathrm{mg} / \mathrm{kg}$ monensin sodium (RUM30, Rumensin, Elanco Animal Health, Indianapolis, IN); iii) $20 \mathrm{mg} / \mathrm{kg}$ lasalocid sodium (BOV20, Bovatec, Alpharma Inc., Bridgewater, NJ), and iv) $30 \mathrm{mg} / \mathrm{kg}$ lasalocid sodium (BOV30). The doses of the ionophores were hand-weighed using a precision balance (Ohaus, mod AS612, Pine Brook, NJ, USA) and premixed in a $2.5 \mathrm{~m}^{3}$ capacity concrete mixer (mod 30910-7, Coyoacán, Mexico) for 5 min with minor ingredients (urea, limestone, and trace mineral salts) and then the final product was mixed (5 min) with the rest of the ingredients to formulate the basal diet. To avoid contamination, the mixer was thoroughly cleaned between each treatment. Dietary treatments were randomly assigned to pens within blocks. To adapt the cattle to ionophores, for the initial $7 \mathrm{~d}$ of trial, ionophores were incorporated into the diet at half of total dose assignment in 
Table 1. Ingredients and composition of diets fed to steers

\begin{tabular}{|c|c|c|c|c|}
\hline \multirow{2}{*}{ Item } & \multicolumn{4}{|c|}{ Supplemental ionophore } \\
\hline & Control & RUM30 & BOV20 & BOV30 \\
\hline \multicolumn{5}{|c|}{ Ingredient composition (\% DM basis) } \\
\hline Steam-flaked corn & 72.00 & 72.00 & 72.00 & 72.00 \\
\hline Cottonseed meal & 3.25 & 3.25 & 3.25 & 3.25 \\
\hline Alfalfa hay & 4.00 & 4.00 & 4.00 & 4.00 \\
\hline Sudan grass hay & 7.00 & 7.00 & 7.00 & 7.00 \\
\hline Tallow & 3.0 & 3.0 & 3.0 & 3.0 \\
\hline Molasses & 8.0 & 8.0 & 8.0 & 8.0 \\
\hline Magnesium oxide & 0.20 & 0.20 & 0.20 & 0.20 \\
\hline Limestone & 1.50 & 1.50 & 1.50 & 1.50 \\
\hline Urea & 0.65 & 0.65 & 0.65 & 0.65 \\
\hline Trace mineral salt ${ }^{1}$ & 0.40 & 0.40 & 0.40 & 0.40 \\
\hline Monensin $(\mathrm{mg} / \mathrm{kg})^{2}$ & 0 & 30 & 0 & 0 \\
\hline Lasalocid $(\mathrm{mg} / \mathrm{kg})^{3}$ & 0 & 0 & 20 & 0 \\
\hline Lasalocid $(\mathrm{mg} / \mathrm{kg})^{3}$ & 0 & 0 & 0 & 30 \\
\hline \multicolumn{5}{|c|}{ NE concentration (Mcal/kg of DM basis $)^{4}$} \\
\hline Maintenance & 2.22 & 2.22 & 2.22 & 2.22 \\
\hline Gain & 1.55 & 1.55 & 1.55 & 1.55 \\
\hline \multicolumn{5}{|c|}{ Nutrient composition (\% of diet DM $)^{5}$} \\
\hline Crude protein & 12.10 & 12.10 & 12.10 & 12.10 \\
\hline Ether extract & 6.12 & 6.12 & 6.12 & 6.12 \\
\hline $\mathrm{NDF}$ & 15.95 & 15.95 & 15.95 & 15.95 \\
\hline Calcium & 0.75 & 0.75 & 0.75 & 0.75 \\
\hline Phosphorus & 0.32 & 0.32 & 0.32 & 0.32 \\
\hline
\end{tabular}

${ }^{1}$ Trace mineral salt contained: $\mathrm{CoSO}_{4}, 0.068 \% ; \mathrm{CuSO}_{4}, 1.04 \% ; \mathrm{FeSO}_{4}, 3.57 \% ; \mathrm{ZnO}, 1.24 \% ; \mathrm{MnSO}_{4}, 1.07 \% ; \mathrm{KI} 0.052 \% ;$ and NaCl, $92.96 \%$.

${ }^{2}$ Elanco Animal Health, Indianapolis, IN. ${ }^{3}$ Alpharma Inc., Bridgewater, NJ.

${ }^{4}$ Based on tabular net energy (NE) values for individual feed ingredients (NRC, 2000) with the exception of supplemental fat, which was assigned NE and $\mathrm{NE}_{\mathrm{g}}$ values of 6.03 and 4.79, respectively (Zinn, 1988).

${ }^{5}$ Dietary composition was determined by analyzing subsamples collected and composited throughout the experiment. Accuracy was ensured by adequate replication with acceptance of mean values that were within $5 \%$ of each other.

each ionophore treatment. Thereafter, the dose was the total assignment. Heifers were allowed ad libitum access to water and to dietary treatments. Daily feed allotments to each pen were adjusted to allow minimal $(<5 \%)$ feed refusals in the feed bunk. The amounts of feed offered and of feed refused were weighed daily. Heifers were provided fresh feed twice daily at 0800 and $1400 \mathrm{~h}$. Feed bunks were visually assessed between 0740 and $0750 \mathrm{~h}$ each morning, refusals were collected and weighed, and feed intake was determined. Adjustments to either increase or decrease daily feed delivery was made at the afternoon feeding. Diets were subjected to the following analyses: DM (oven drying at $105^{\circ} \mathrm{C}$ until no further weight loss; method 930.15; AOAC, 2000); crude protein $(\mathrm{N} \times 6.25$, method 984.13; AOAC, 2000); ash (method 942.05; AOAC, 2000); neutral detergent fibre [Van Soest et al., 1991; corrected for NDFash, incorporating heat stable $\alpha$-amylase (Ankom Technology, Macedon, NY) at $1 \mathrm{~mL}$ per $100 \mathrm{~mL}$ of NDF solution (Midland Scientific, Omaha, NE)]; ether extract (method 920.39; AOAC, 2000); starch (Zinn, 1990) and calcium, (method 927.02; AOAC, 2000), and phosphorus (method 964.06; AOAC, 2000). Feed and refusal samples were collected daily for DM analysis, which involved oven drying the samples at $105^{\circ} \mathrm{C}$ until no further weight loss occurred (method 930.15, AOAC, 2000). The ionophore concentration in the premix was determined by an independent laboratory (Laboratorio de Constatación Agroindustrial, SA de CV, México, DF).

\section{Estimation of dietary NE}

The estimations of expected DMI and dietary energetic were performed based on measures of initial and final shrunk body weight (SBW), assuming that SBW is $96 \%$ of full weight (NRC, 2000). Average daily gains (ADG) were computed by subtracting the initial $\mathrm{BW}$ from the final $\mathrm{BW}$ and dividing the result by the number of days on feed. The efficiency of BW gain was computed by dividing ADG by the daily DMI. The estimation of expected DMI was performed based on the observed ADG and SBW according to the following equation: expected DMI, $\mathrm{kg} / \mathrm{d}=\left(\mathrm{EM} / \mathrm{NE}_{\mathrm{m}}\right)$ $+\left(\mathrm{EG} / \mathrm{EN}_{\mathrm{g}}\right)$, where $\mathrm{EM}$ (energy required for maintenance, $\mathrm{Mcal} / \mathrm{d})=0.077 \mathrm{~W}^{0.75}$ (Garrett, 1971), EG $=\mathrm{ADG}^{1.097} \times$ 
$0.0608 \mathrm{~W}^{0.75}$ (NRC, 1984), $\mathrm{NE}_{\mathrm{m}}$ and $\mathrm{NE}_{\mathrm{g}}$ are 2.22 and 1.55 $\mathrm{Mcal} / \mathrm{kg}$, respectively (derived from tabular values based on the ingredient composition of the experimental diet; NRC, 2000). The dietary $\mathrm{NE}_{\mathrm{g}}$ was derived from $\mathrm{NE}_{\mathrm{m}}$ by the equation: $\mathrm{NE}_{\mathrm{g}}=0.877 \mathrm{NE}_{\mathrm{m}}-0.41$ (Zinn, 1987). Dry matter intake is related to energy requirements and dietary $\mathrm{NE}_{\mathrm{m}}$ according to the equation: $\mathrm{DMI}=\mathrm{EG} /\left(0.877 \mathrm{NE}_{\mathrm{m}}-0.41\right)$, and can be resolved for estimation of dietary NE by means of the quadratic formula: $x=\frac{-b \pm \sqrt{b^{2}-4 a c}}{2 c}$, where $x=$ $\mathrm{NE}_{\mathrm{m}}, a=-0.41 \mathrm{EM}, b=0.877 \mathrm{EM}+0.41 \mathrm{DMI}+\mathrm{EG}$, and $c=$ -0.877 DMI (Zinn and Shen, 1998).

\section{Carcass data}

All heifers were harvested on the same day. Hot carcass weights $(\mathrm{HCW})$ were obtained from all heifers at the time of slaughter. After carcasses were chilled for $48 \mathrm{~h}$, the following measurements were obtained: i) LM area, taken by direct grid reading of the muscle at the 12 th rib taken at a location three-quarters of the length laterally from the backbone end; ii) subcutaneous fat over the ribeye muscle at the 12th rib taken at a location three-quarters of the lateral length from the chin bone end; iii) kidney, pelvic and heart fat $(\mathrm{KPH})$ as a percentage of carcass weight and iv) marbling score (USDA, 1997).

\section{Statistical analyses}

Performance (gain, gain efficiency, and dietary energetics) and carcass data were analysed as a randomised complete block design. The experimental unit was the pen. The MIXED procedure of SAS (SAS Institute, 2004) was used to analyse the variables. The fixed effect consisted of treatment, and pen as the random component. Feed additive effects (ionophores) were tested by means of orthogonal contrasts. Contrasts were considered significant when the pvalue was $\leq 0.05$, and tendencies were identified when the p-value was $>0.05$ and $\leq 0.10$. To measure the effect of THI on DM intake, a covariance analysis was computed using the MIXED procedure of SAS (SAS, 2004). Regression coefficients for each of the treatments were generated, specifying the SOLUTION option in the model statement. When the interaction of the treatment effect with the THI variable was significantly different from zero, a test for the heterogeneity of slopes was applied to data using a t-test. The comparisons between regression coefficients were done using the ESTIMATE statement.

\section{RESULTS AND DISCUSSION}

Before starting with the discussion of the results, it is important to mention that the use of antimicrobials as feed additives in food animal production remains very controversial, and the practice is banned in many countries, including those in the European Union (Clark et al., 2011). The major concerns relate to the potential for selecting for antimicrobial resistance factors and the subsequent transfer of these from food-producing animals to food, and therefore to the consuming public (Fajt, 2007).

Ambient weather conditions during the course of the study is shown in Table 2. Minimum and maximum air temperature averaged 23.6 and $42.5^{\circ} \mathrm{C}$, respectively, with average maximum temperature exceeding $35^{\circ} \mathrm{C}$ in every week of the study. Relative humidity averaged $35 \%$. THI averaged $79.2 \pm 2.3$, with minimum and maximums of 70 and 93, respectively. Igono et al. (1992) proposed that cattle are under a condition of heat stress when THI exceeds 72 . Accordingly, cattle were subject to heat stress throughout the course of the experiment.

Treatments effects on growth performance and dietary energetics in feedlot heifers is shown in Table 3. Differences between the comparisons RUM30 vs BOV20 and BOV20 vs BOV30 treatments were not significant $(\mathrm{p}>0.10)$. Thus, the $\mathrm{p}$-values for these comparisons are not presented in the tables. Compared to controls, monensin supplementation did not influence average daily gain, estimated dietary NE or observed-to-expected DMI, but tended $(\mathrm{p}=0.07)$ to increase $(4.8 \%)$ gain to feed. The

Table 2. Ambient temperature (Ta), mean relative humidity (RH), mean temperature-humidity index (THI), mean wind speed (WS), and solar radiation (SR) registered during experiment

\begin{tabular}{|c|c|c|c|c|c|c|c|c|c|c|c|}
\hline Week & $\begin{array}{c}\text { Mean } \mathrm{T}_{\mathrm{a}} \\
\left({ }^{\circ} \mathrm{C}\right)\end{array}$ & $\begin{array}{c}\operatorname{Max} \mathrm{T}_{\mathrm{a}} \\
\left({ }^{\circ} \mathrm{C}\right)\end{array}$ & $\begin{array}{c}\operatorname{Min} \mathrm{T}_{\mathrm{a}} \\
\left({ }^{\circ} \mathrm{C}\right)\end{array}$ & $\begin{array}{c}\text { Mean RH } \\
(\%)\end{array}$ & $\begin{array}{c}\text { Max RH } \\
(\%)\end{array}$ & $\begin{array}{c}\text { Min RH } \\
(\%)\end{array}$ & Mean THI ${ }^{1}$ & Max THI & Min THI & $\mathrm{WS} / \mathrm{m} / \mathrm{s}$ & SR \\
\hline 1 & 34.9 & 41.5 & 28.7 & 35.0 & 58.7 & 18.4 & 81.5 & 95.4 & 72.0 & 1.9 & 308 \\
\hline 2 & 34.4 & 41.3 & 28.0 & 43.7 & 67.1 & 22.5 & 82.6 & 97.3 & 71.9 & 2.5 & 279 \\
\hline 3 & 33.0 & 38.8 & 27.4 & 50.7 & 77.0 & 28.9 & 82.0 & 96.0 & 71.9 & 1.0 & 236 \\
\hline 4 & 35.3 & 42.5 & 28.0 & 25.6 & 50.0 & 11.0 & 78.9 & 94.2 & 70.3 & 0.9 & 280 \\
\hline 5 & 31.4 & 38.2 & 24.7 & 39.4 & 65.9 & 20.1 & 77.9 & 92.3 & 68.2 & 1.6 & 247 \\
\hline 6 & 32.1 & 39.0 & 29.9 & 27.1 & 44.9 & 15.3 & 76.9 & 88.7 & 68.1 & 1.2 & 268 \\
\hline 7 & 34.7 & 41.6 & 27.9 & 30.3 & 56.5 & 12.0 & 80.3 & 94.9 & 70.3 & 1.2 & 248 \\
\hline 8 & 29.7 & 36.4 & 23.6 & 26.0 & 40.4 & 14.1 & 74.0 & 84.2 & 66.6 & 1.9 & 235 \\
\hline
\end{tabular}

${ }^{1} \mathrm{THI}=0.81 \times$ ambient temperature $+[$ (relative humidity $\times($ ambient temperature -14.4$)]+46.4$. 
may be partially due to changes in maintenance energy in heat stressed cattle, rather than notable changes in ruminal fermentation patterns (Armstrong and Spears, 1988; Benz et al., 1989).

Observed concentrations of lasalocid in BOV20 and BOV30 were 18.4 and $27.4 \mathrm{mg} / \mathrm{kg}$, respectively (in good agreement with diet formulation, Table 1). Differences cattle growth performance responses due to dietary lasalocid concentration (BOV20 vs BOV30) were not statistically significant ( $\mathrm{p}>0.10)$. In contrast, Mader et al. (1985) reported a linear response in weight gain and feed efficiency on the entire feeding period when finishing cattle were supplemented with $0,11,22$, or $33 \mathrm{mg} / \mathrm{kg}$ of lasalocid.

Compared to controls, the heifers fed BOV20 had greater feed efficiency $(p=0.02)$ with small effects on the rest of the variables. Compared to controls, heifers fed BOV30 had greater $(\mathrm{p} \leq 0.03)$ ADG $(11.8 \%)$, gain to feed $(8.3 \%)$, dietary net energy (5\%) and observed-to-expected DMI (5.2\%). Increases in ADG, feed efficiency and/or both, has been a consistent response to lasalocid supplementation (Mader et al., 1985; Zinn, 1987). The magnitude of enhancements in ADG and gain to feed observed in the present study are greater than those reported by Mader et al. (1985) and Berger et al. (1981).

Consistent with Zinn (1987), heifers supplementation with BOV30 had greater ADG $(7 \%, \mathrm{p}=0.05)$ than heifers supplemented with RUM30. Otherwise, differences between two ionophore treatments with respect to gain to feed and dietary net energy were not statistically significant. However, in other studies (Berger et al., 1981; Beacom et al., 1988), there were no differences in weight gain between cattle fed monensin vs lasalocid. Difference in ADG between monensin and lasalocid in some reports is more a reflection of differences in energy intake rather than differences in energetic efficiency.

Overall (56-d feeding period), DM intake was not different $(\mathrm{p} \geq 0.40)$ between treatments. However, when average daily THI values were $\leq 77$, observed feed intake of heifers fed the control diet was greater (Figure 1, p<0.05) than that of the heifers supplemented with ionophore treatments. In contrast, when average daily THI values were $>79$, the DMI of controls was not different $(p=0.42)$ than that of the monensin group. However, under this condition of greater thermal stress (average daily THI values >79), the DMI of both control and RUM30 supplemented heifers was less $(p=0.04)$ than that of lasalocid supplemented heifers. Based on prediction equation for estimation of DMI in nonstressed (thermoneutral conditions) feedlot cattle (NRC, 2000), heifers fed the control diet consumed 8.3\% less DM less than predicted, whereas RUM30 and BOV (average of both treatments) groups consumed 8.3 and 6.8\% less DM than predicted, respectively. Mader et al. (2003) developed the following equation which can be used to describe the effects of THI on DMI: DMI, as \% of change $=229.74+$ $7.2125 \mathrm{THI}-0.0561 \mathrm{THI}^{2}$. Accordingly, expected change in DMI was $-10.4 \%$; in good agreement with observed reductions in DM intake observed in the present trial.

As mentioned previously, monensin did not affect DMI. Generally, inclusion of monensin to finishing diets reduces DM intake. Early reviews of the research on monensin indicate that including monensin in high-energy finishing diets reduces DMI by an average of 5\% (Schelling, 1984) to $7.5 \%$ (Goodrich et al., 1984). More recent estimates suggest that the reduction in feed intake is only $3 \%$, consistent with to the higher energy finishing rations now utilised (Duffield et al., 2012); this is in close agreement with the reduction in DMI of $2.8 \%$ in the monensin group when the THI value was less than 79. Heifers fed lasalocid maintained a similar consumption level throughout the experiment (Figure 1). Feed intake response to lasalocid inclusion is consistent with previous work. Fox et al. (1988) suggested that feed intake is decreased by $2 \%$ by lasalocid, irrespective of the concentration.

Consistent with Gibb et al. (2001), the coefficient of

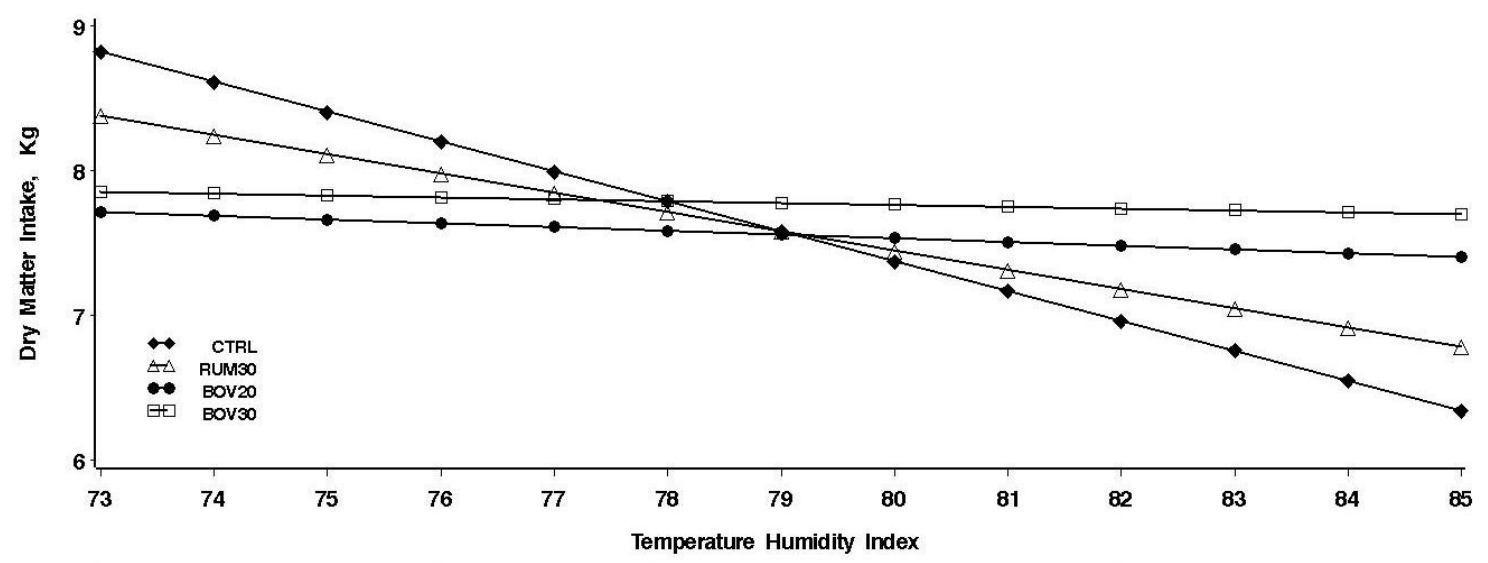

Figure 1. Average dry matter intake relative to the temperature humidity index (THI) measured during the experiment. Treatments are: $\mathrm{CTRL}=$ Control, RUM30 = Monensin $30 \mathrm{mg} / \mathrm{kg}$, BOV20 = Lasalocid $20 \mathrm{mg} / \mathrm{kg}$, BOV30 = Lasalocid $30 \mathrm{mg} / \mathrm{kg}$. 
Table 4. Treatments effects on carcass characteristics in feedlot heifers

\begin{tabular}{|c|c|c|c|c|c|c|c|c|c|}
\hline \multirow[b]{2}{*}{ Item } & \multirow[b]{2}{*}{ Control } & \multicolumn{3}{|c|}{ Ionophore $^{1}$} & \multirow[b]{2}{*}{ SEM } & \multicolumn{4}{|c|}{$\mathrm{p}^{2}$ value } \\
\hline & & RUM30 & BOV20 & BOV30 & & $\begin{array}{c}\text { C vs } \\
\text { RUM30 }\end{array}$ & $\begin{array}{c}\text { C vs } \\
\text { BOV20 }\end{array}$ & $\begin{array}{c}\text { C VS } \\
\text { BOV30 }\end{array}$ & $\begin{array}{c}\text { BOV30 vs } \\
\text { RUM30 }\end{array}$ \\
\hline$\overline{\mathrm{HCW}}(\mathrm{kg})$ & 282.2 & 284.1 & 284.8 & 288.7 & 2.53 & 0.60 & 0.48 & 0.10 & 0.23 \\
\hline Dressing $(\%)$ & 63.03 & 62.88 & 62.97 & 63.16 & 0.56 & 0.86 & 0.95 & 0.87 & 0.73 \\
\hline $\mathrm{LM}\left(\mathrm{cm}^{2}\right)$ & 85.48 & 87.15 & 89.02 & 90.08 & 2.53 & 0.65 & 0.35 & 0.23 & 0.43 \\
\hline Fat thickness $(\mathrm{cm})$ & 0.79 & 0.74 & 0.81 & 0.73 & 0.08 & 0.43 & 0.87 & 0.37 & 0.92 \\
\hline $\mathrm{KPH}(\%)$ & 2.40 & 2.62 & 2.46 & 2.52 & 0.13 & 0.23 & 0.75 & 0.53 & 0.56 \\
\hline Marbling score & 3.39 & 3.20 & 3.29 & 3.20 & 0.15 & 0.37 & 0.63 & 0.37 & 0.99 \\
\hline
\end{tabular}

${ }^{1} \mathrm{MON}=$ Monensin (Rumensin, Elanco Animal Health, Indianapolis, IN); BOV = Lasalocid (Bovatec,Alpharma Inc., Bridgewater, NJ).

${ }^{2} p=$ Observed significance level for effect of treatments. ${ }^{3}$ Coded: minimum slight $=3$, minimum small $=4$, etc.

variation in energy intake was lower $(p<0.05)$ in the ionophores supplemented heifers $(\mathrm{CV}=1.7 \%)$ than in heifers fed the control diet $(\mathrm{CV}=4.5 \%)$. Fluctuations in intake of high-concentrate diets may be causative factor in incidence of subacute acidosis (Stock et al., 1995a). SotoNavarro et al. (2000b) observed that ruminal $\mathrm{pH}$ at $0,3,18$, and $24 \mathrm{~h}$ after feeding was greater in steers fed at a constant rate than for steers exposed to a $10 \%$ fluctuation in daily feed intake. Galyean et al. (1992) observed that compared to a constant rate of feeding, a $10 \%$ fluctuation in feed allowance depressed both ADG (6.5\%) and gain to feed (7\%). However, it appears that may adapt to feed intake fluctuations, so that in the long-term, no adverse effects on gain or gain to feed are observed (Zinn, 1994; Stock et al. 1995b; Soto-Navarro et al., 2000a).

An alternative approach for expressing ionophore effects on animal energetics in the present experiment is to let the net energy value of the diet remain constant and present treatment effects solely as a function of changes in the maintenance coefficient (Zinn, 1987). In this manner, ionophore supplementation reduced the estimated maintenance coefficients by 8.6 and $12.7 \%$ in the monensin and lasalocid groups, respectively.

The effects of treatments on carcass characteristics are shown in Table 4. As in previous studies (Zinn, 1987; 1988; Montgomery et al., 2003), there were no effects of ionophore supplementation on carcass characteristics. Beerman (1995) concluded that the effects of ionophores on dressing percentage and carcass composition are too small to be of economic importance.

It is concluded that ionophore supplementation did not exacerbate the decline in DM intake in heat-stressed cattle (THI> 79) fed a high-energy finishing diet. On the contrary, ionophore supplementation reduced variation in energy intake, favouring feed efficiency. Ionophore supplementation reduced the estimated maintenance coefficients by around $10 \%$ in finishing cattle during a period of heat stress. These responses were greater when the ionophore lasalocid was supplemented at a level of 30 $\mathrm{mg} / \mathrm{kg}$ of diet.

\section{REFERENCES}

AOAC. 2000. Official methods of analysis, 17th edn. Association of Official Analytical Chemists, Gaithersburg, Maryland.

Armstrong, J. D. and J. W. Spears. 1988. Intravenous administration of ionophores in ruminants: effects on metabolism independent of the rumen. J. Anim. Sci. 66:18071817.

Bartley, E. E., E. L. Herod, R. M. Bechtle, D. A. Sapienza, and B. E. Brent. 1979. Effect of monensin or lasalocid, with and without niacin or amicloral, on rumen fermentation and feed efficiency. J. Anim. Sci. 49:1066-1075.

Beacom, S. E., Z. Mir, G. O. Korsrud, W. G. D. Yates, and J. D. MacNeil. 1988. Effect of the feed additives chlortetracycline, monensin and lasalocid on feedlot performance of finishing cattle, liver lesions and tissue levels of chlortetracycline. Can. J. Anim. Sci. 68:1131-1141.

Beermann, D. H. 1995. Growth promotants-promise, problems, and perceptions. Proc. Reciprocal Meat Conf. 48:45-50.

Benz, D. A., F. M. Byers, G. T. Schelling, L. W. Greene, D. K. Lunt, and S. B. Smith. 1989. Ionophores alter hepatic concentrations of intermediary carbohydrate metabolites in steers. J. Anim. Sci. 67:2393-2399.

Bergen, W. G. and D. B. Bates. 1984. Ionophores: their effect on production efficiency and mode of action. J. Anim. Sci. 58: 1465-1483.

Berger, L. L., S. C. Ricke, and G. C. Fahey. 1981. Comparison of two forms and two levels of lasalocid with monensin on feedlot cattle performance. J. Anim. Sci. 53:1440-1445.

Clark, S., R. Daly, E. Jordan, J. Lee, A. Mathew, and P. Ebner. 2012. EXTENSION EDUCATION SYMPOSIUM: The future of biosecurity and antimicrobial use in livestock production in the United States and the role of extension. J. Anim. Sci. 90:2861-2872.

Correa-Calderón, A., J. A. Hernández-Rivera, L. Avendaño-Reyes, U. Macías-Cruz, R. Díaz-Molina, F. D. Alvarez-Valenzuela, and A. González-Reyna. 2012. Reproductive performance and serum concentrations of progesterone of heat-stressed Holstein heifers subjected to timed artificial insemination and progesterone supplementation. Turk. Vet. Anim. Sci. 36:611616. 
Delfino, J., G. W. Mathison, and M. W. Smith. 1988. Effect of lasalocid on feedlot performance and energy partitioning in cattle. J. Anim. Sci. 66:136-150.

Depenbusch, B. E., J. S. Drouillard, E. R. Loe, J. J. Higgins, M. E. Corrigan, and M. J. Quinn. 2008. Efficacy of monensin and tylosin in finishing diets based on steam-flaked corn with and without corn wet distillers grains with solubles. J. Anim. Sci. 86: $2270-2276$.

Di Lorenzo, N. and M. L. Galyean. 2010. Alpharma Beef Cattle Nutrition Symposium - Alternative Energy Sources in HighEnergy Diets for Beef Cattle: Challenges, Benefits, and Management Options Applying technology with newer feed ingredients in feedlot diets: Do the old paradigms apply? J. Anim. Sci. 88:E123-E132.

Duff, G. C. and M. L. Galyean. 2007. BOARD-INVITED REVIEW: Recent advances in management of highly stressed, newly received feedlot cattle. J. Anim. Sci. 85:823-840.

Duffield, T. F., J. K. Merrill, and R. N. Bagg. 2012. Meta-analysis of the effects of monensin in beef cattle on feed efficiency, body weight gain, and dry matter intake. J. Anim. Sci. 90: 4583-4592.

Erickson, P. S., M. L. Davis, C. S. Murdock, K. E. Pastir, M. R. Murphy, G. C. Schwab, and J. I. Marden. 2004. Ionophore taste preferences of dairy heifers. J. Anim. Sci. 82:3314-3320.

Fajt, R. V. 2007. Regulation of drugs used in feedlot diets. In: Veterinary Clinics of North America (Ed. L. C. Hollis and K. C. Olson) Elsevier Saunders, New York, NY. pp. 23:299-307.

Fox, D. G., C. J. Sniffen, and J. D. O’Connor. 1988. Adjusting nutrient requirements of beef cattle for animal and environmental variations. J. Anim. Sci. 66:1475-1495.

Galyean, M. L., K. J. Malcom, D. R. García, and G. D. Pulsipher. 1992. Effects of varying the pattern of feed consumption on performance by programmed-fed steers. New Mexico State University. Research Agricultural Experimental Station. PR. 78.

García, E. 1985. Modificaciones al sistema de clasificación climática de Köppen para adaptarlo a las condiciones de la República Mexicana. 2nd edn. Instituto de Geografía, Universidad Nacional Autónoma de México, México, DF (In spanish).

Garret, W. 1971. Energetic efficiency of beef and dairy steers. J. Anim. Sci. 31:452-456.

Gibb, D. J., S. M. S. Moustafa, R. D. Wiedmeier, and T. A. McAllister. 2001. Effect of salinomycin or monensin on performance and feeding behaviour of cattle fed wheat- or barley-based diets. Can. J. Anim. Sci. 81:253-261.

Goodrich, R. D., J. E. Garrett, D. R. Gast, M. A. Kirick, D. A. Larson, and J. C. Meiske. 1984. Influence of monensin on the performance of cattle. J. Anim. Sci. 58:1484-1498.

Hahn, G. L. 1999. Dynamic responses of cattle to thermal heat loads. J. Anim. Sci. 77:10-20.

Igono, M. O., G. Bjotvedt, and H. T. Sanford-Crane. 1992. Environmental profile and critical temperature effects on milk production of Holstein cows in desert climate. Int. J. Biometeorol. 36:77-87.

National Research Council. 1981. Effect of environment on nutrient requirements of domestic animals. National Academy Press, Washington, DC.

National Research Council. 1984. Nutrient requirements of beef cattle. 6th ed. National Academy Press, Washington, DC.

National Research Council. 1987. Predicting feed intake of foodproducing animals. National Academy Press, Washington, DC.

National Research Council. 2000. Nutrient requirements of beef cattle. Updated 7th ed. National Academy Press, Washington, DC.

Macías-Cruz, U., F. D. Álvarez-Valenzuela, A. Correa-Calderón, R. Díaz-Molina, M. Mellado, C. Meza-Herrera, and L. AvendañoReyes. 2013. Thermoregulation of nutrient-restricted hair ewes subjected to heat stress during late pregnancy. J. Therm. Biol. 38:1-9.

Mader, T. L. 2003. Environmental stress in confined beef cattle. J. Anim. Sci. 81:E110-E119.

Mader, T. L., L. W. Lomas, and I. G. Rush. 1985. Lasalocid in liquid supplements for finishing feedlot cattle. Can. J. Anim. Sci. 65:891-896.

Montgomery, S. P., J. S. Drouillard, J. J. Sindt, T. B. Farran, H. J. Labrune, and R. D. Hunter. 2003. Effects of monensin and tylosin concentrations in limit-fed, high-energy growing diets for beef cattle. Prof. Anim. Sci. 19:244-250.

Page, S. W. 2003. The Role of Enteric Antibiotics in Livestock Production. Avcare Limited. Canberra.

Raun, A. P., C. O. Cooley, E. L. Potter, R. P. Rathmacher, and L. F. Richardson. 1976. Effect of monensin on feed efficiency of feedlot cattle. J. Anim. Sci. 43:670-677.

Russell, J. B. and H. J. Strobel. 1988. Effects of additives on in vitro ruminal fermentation: a comparison of monensin and bacitracin, another gram-positive antibiotic. J. Anim. Sci. 66: $552-558$.

Schelling, G. 1984. Monensin mode of action in the rumen. J. Anim. Sci. 58:1518-1527.

Soto-Navarro, S. A., G. C. Duff, C. R. Krehbiel, M. L. Galyean, and K. J. Malcolm-Callis. 2000a. Influence of feed intake fluctuation, feeding frequency, time of feeding, and rate of gain on performance by limit-fed steers. Prof. Anim. Sci. 16: 13-20.

Soto-Navarro, S. A., C. R. Krehbiel, G. C. Duff, M. L. Galyean, M S. Brown, and R. L. Steiner. 2000b. Influence of feed intake fluctuation and frequency of feeding on nutrient digestion, digesta kinetics, and ruminal fermentation profiles in limit-fed steers. J. Anim. Sci. 78:2215-2222.

Spires, H. R., A. Olmsted, L. L. Berger, J. P. Fontenot, D. R. Gill, J. G. Riley, M. I. Wray, and R. A. Zinn. 1990. Efficacy of laidlomycin propionate for increasing rate and efficiency of gain by feedlot cattle. J. Anim. Sci. 68:3382-3391.

Stock, R. A., M. H. Sindt, J. C. Parrott, and F .K. Goedeken. 1990. Effects of grain type, roughage level and monensin level on finishing cattle performance. J. Anim. Sci. 68:3441-3455.

Stock, R. A., S. B. Laudert, W. W. Stroup, E. M. Larson, J. C. Parrott, and R. A. Britton. 1995a. Effect of monensin and monensin and tylosin combination on feed intake variation of feedlot steers. J. Anim. Sci. 73:39-44.

Stock, R., T. Klopfenstein, and D. Shain.1995b. Feed intake variation. In: Symposium; Feed Intake by Feedlot Cattle. Oklahoma Agriculture Experimental Station. P-942, 56-59.

USDA. 1997. United States Standards for Grading of Carcass Beef. Agricultural Marketing Service, United States Department of Agriculture, Washington, DC. 
Zinn, R. A. 1986. Influence of forage level on response of feedlot steers to salinomycin supplementation. J. Anim. Sci. 63:20052012.

Zinn, R. A. 1987. Influence of lasalocid and monensin plus tylosin on comparative feeding value of steam-flaked versus dryrolled corn diets for feedlot cattle. J. Anim. Sci. 65:256-266.
Zinn, R. A. 1988. Comparative feeding value of supplemental fat in fi nishing diets for feedlot steers supplemented with and without monensin. J. Anim. Sci. 66:213-227.

Zinn, R. A. 1994. Influence of fluctuating feed intake on feedlot cattle growth-performance and digestive function. In: Southwest Nutrition Manaz. 